\title{
Perilaku Menyimpang Praktik Bisnis Periklanan dalam Perspektif Hukum Pidana dan Penegakan Hukumnya
}

\author{
Hanafi Amrani \\ Fakultas Hukum Universitas Islam Indonesia \\ Jln. Tamansiswa 158 Yogyakarta \\ h.amrani@yahoo.com
}

\begin{abstract}
This research is aimed to analyze the criteria and form of deviation behaviour in business practice of advertisement and the deviation behaviour in business practice in the perspective of criminal law and its legal enforcement. This is a normative legal research using the regulation approach and concept approach. The data was collected and analysed using the descriptive - qualitative method. The result of the research showed that first; there are two criteria to show the deviation behaviour: fact of material and rationale consumers. Meanwhile, a number of deviations in presenting the information of advertisement through mass media including presenting the information falsely (false statement), revealing the fact misleadingly (mislead statement), giving the description incompletely (omission), giving the exaggerating opinion without any support of fact (puffery), and advertisement is contradicting with politeness, moral and ethics. Second, in the perspective of criminal law, the deviation behaviour can be categorized as the criminal act. The problem in this research is related to the legal enforcement particularly related to the unequal perception between society and the law enforcers in responding the deviation behaviour in the business practice of advertisement whether it is included in business tort or business crime. Other factor that is also impacting the enforcement of criminal law is related to the evidence, mentality of the law enforcers and society and political will of government in doing an action towards the business activity of deviating advertisement.
\end{abstract}

Keywords: Deviation behaviour, business practice of advertisement, criminal law

\section{Abstrak}

Penelitian ini mengkaji kriteria dan bentuk perilaku menyimpang dalam praktik bisnis periklanan, serta perilaku menyimpang dalam praktik bisnis ditinjau dari hukum pidana dan penegakan hukumnya. Penelitian ini termasuk penelitian hukum normatif dengan pendekatan undang-undang dan pendekatan konsep. Data yang terkumpul dianalisis dengan metode deskriptif kualitatif. Hasil penelitian menunjukkan bahwa, pertama, terdapat dua kriteria untuk menunjukkan adanya perilaku menyimpang dalam praktik bisnis periklanan, yaitu fakta material dan konsumen rasional. Sementara itu, beberapa bentuk penyimpangan dalam penayangan informasi iklan melalui media massa meliputi: pemberian informasi secara keliru (false statement), pegungkapan pernyataan yang menyesatkan (mislead statement), memberikan gambaran secara tidak lengkap (omission), memberikan opini yang berlebihan tanpa didukung fakta (puffery), serta iklan yang bertentangan dengan kesopanan, moral, dan kesusilaan. Kedua, dalam perspektif hukum pidana sebagian besar perilaku menyimpang tersebut dapat dikategorikan sebagai perbuatan pidana. Yang menjadi permasalahan adalah terkait dengan penegakan hukumnya, terutama menyangkut persepsi yang tidak sama antara masyarakat dengan penegak hukum dalam mensikapi perilaku menyimpang praktik bisnis periklanan, apakah termasuk business tort ataukah business crime. Faktor lain yang juga berpengaruh terhadap penegakan hukum pidana adalah masalah pembuktian, sikap mental aparat penegak hukum maupun masyarakat, serta political will pemerintah dalam melakukan tindakan terhadap aktivitas bisnis periklanan yang menyimpang tersebut.

Kata-kata Kunci: perilaku menyimpang, praktik bisnis periklanan, hukum pidana 


\section{Pendahuluan}

Iklan dapat dikategorikan sebagai komunikasi komersil dan nonpersonal tentang sebuah organisasi dan produk-produknya yang ditransmisikan ke suatu khalayak target melalui media bersifat massal seperti televisi, radio, koran, majalah, direct mail (pengeposan langsung), reklame luar ruang, atau kendaraan umum. ${ }^{1}$ Bagi pelaku usaha, iklan dapat lebih mendekatkan diri kepada konsumen dengan menawarkan aneka produk yang sesuai dengan keinginan dan kebutuhan konsumen. Pentingnya media iklan bagi pelaku usaha tergambar dari-pendapat David Oughnton dan John Lowry: 'Advertising is the central symbol of consumer society, advertising plays a central role in making available to consumers information which the producers of the advertised product wishes the consumer to have'. ${ }^{2}$ Senada dengan itu, Wright ${ }^{3}$ mengemukakan bahwa iklan merupakan suatu proses komunikasi yang mempunyai kekuatan sebagai alat pemasaran yang membantu menjual barang, memberikan layanan, serta gagasan atau ide-ide melalui saluran tertentu dalam bentuk informasi yang persuasif.

Iklan yang baik haruslah memuat informasi yang benar, jujur, apa adanya, dan sesuai dengan kenyataan, karena mendapatkan informasi yang benar dan jujur adalah hak konsumen. ${ }^{4}$ Dalam Tata Cara Periklanan Indonesia terdapat asas umum yaitu iklan harus jujur, bertanggung jawab, dan tidak bertentangan dengan hukum yang berlaku. Namun di sisi lain, dalam kenyataannya iklan tidak lagi menampilkan sifat informatif yang berfungsi menerangkan karakteristik dari barang/jasa yang ditawarkan, namun tidak sedikit iklan hanya berisi janji kosong, tidak realistis, dan tidak proporsional yang bertujuan menyesatkan konsumen.

Contoh mengenai pemberian informasi tidak benar melalui periklanan yang dapat merugikan konsumen adalah: 'makanan ini mengandung zat yang dapat mencerdaskan anak', 'aku tumbuh sehat dan menjadi nomor satu karena minum susu $X^{\prime}$. Sementara itu pemakaian opini yang berlebihan tanpa fakta tertentu dapat diberikan contoh seperti pemakaian kata-kata 'nomor satu', 'terbaik', 'terpilih',

\footnotetext{
${ }^{1}$ Monle Lee \& Carla Johnson, Prinsip-prinsip Pokok Periklanan dalam Perspektif Global, Kencana Prenada Media Group, Jakarta, 2007, hlm. 3.

2Oughton, David, dan Jhon Lowry, The Text Book on Consumer Law, Black Stone Press Limited, London, 1997, hlm. 65 .

${ }^{3}$ Alo Liliweri, Dasar-dasar Komunikasi Periklanan. PT. Citra Aditya Bhakti, Bandung, 1992, hlm. 20.

4Janus Sidabalok, Hukum Perlindungan Konsumen di Indonesia, PT. Citra Aditya Bakti, Bandung, 2006, hlm. 245.
} 
'menjadikan masakan lebih enak', 'mencuci lebih bersih'. Juga ada iklan dengan ungkapan yang menyesatkan seperti penawaran harga 'obral', 'paling murah', 'beli rumah dapat parabola', dan lain-lain. Contoh lain adalah iklan yang tidak sesuai dengan kenyataan, seperti obat maag yang mempromosikan seolah-olah produk itu dapat mencegah agar tidak mengalami gangguan lambung selama berpuasa. Padahal obat yang mengandung antisida itu berfungsi hanya untuk mengurangi keluhan lambung, bukan untuk mencegah menderita sakit maag karena berpuasa.

Sehubungan dengan hal tersebut, seorang ahli periklanan Marshall Mc Luhan, jauh hari sebelumnya juga sudah mengatakan bahwa kemunculan industri periklanan telah membangkitkan kekuatiran masyarakat tentang adanya unsur ketidakjujuran atau pembohongan di bidang usaha ini. Selanjutnya dikatakan, industri periklanan berusaha membuat masyarakat menjadi masyarakat yang kolektif yang otomatis terprogram pada produk yang diiklankan. Pesan tersebut mengandung beberapa aspek seperti image, gambar, dan juga suara yang secara keseluruhan merupakan suatu konstruksi utuh yang mampu membujuk, mempengaruhi, dan merubah persepsi. Karena kespesifikannya inilah maka industri periklanan tidak mampu melepaskan diri dari rasa kecurigaan masyarakat terhadap kejujurannya. Ditambah lagi semangat berkompetisi yang amat keras dipacu sehingga menyebabkan terjadinya kreatifitas yang melanggar etika. ${ }^{5}$

Berdasarkan fakta-fakta tersebut di atas dapat diperoleh gambaran bahwa iklan yang menurut fungsinya sebagai alat komunikasi antara pelaku usaha yang menyampaikan pesan-pesan khasnya berupa informasi persuasif sekitar barang dan/atau jasa, namun dalam kenyataannya tidak sedikit iklan tersebut justru menyesatkan masyarakat. Iklan yang disiarkan melalui media massa banyak yang bersifat pemberian informasi yang tidak benar atau bohong untuk memperoleh keuntungan yang bertentangan dengan hukum dan etika. Menghadapi fenomena semacam ini perlu dilakukan penelitian terkait perilaku menyimpang praktik bisnis periklanan dan bagaimana perilaku menyimpang tersebut apabila ditinjau dari aspek hukum pidana dan penegakan hukumnya.

${ }^{5}$ BPHN, "Naskah Akademis Peraturan Perundang-undangan tentang Perlindungan Konsumen dalam Hal Makanan dan Minuman”, BPHN, Jakarta, hlm.31. 


\section{Rumusan Masalah}

Berdasarkan uraian pada latar belakang masalah tersebut di atas, penelitian ini difokuskan untuk menjawab dua pertanyaan berikut. Pertama, apa kriteria dan bentuk perilaku menyimpang dalam praktik bisnis periklanan? Kedua, bagaimana perilaku menyimpang dalam praktik bisnis periklanan tersebut ditinjau dari aspek hukum pidana dan penegakan hukumnya?

\section{Tujuan Penelitian}

Penelitian ini bertujuan: pertama, mengkaji dan menjelaskan kriteria dan bentuk perilaku menyimpang praktik bisnis periklanan; dan kedua, perilaku menyimpang dalam praktik bisnis periklanan tersebut ditinjau dari aspek hukum pidana dan penegakan hukumnya.

\section{Metode Penelitian}

Penelitian ini dapat dikategorikan sebagai penelitian deskriptif-kualitatif, yaitu penggambaran secara mendalam tentang situasi atau proses yang diteliti. ${ }^{6}$ Penelitian deskriptif-kualitatif dalam konteks ini dimaksudkan untuk memberikan deskripsi mengenai kondisi, siatuasi, dan fenomena praktik bisnis periklanan ditinjau dari perspektif hukum pidana dan penegakan hukumnya. Dalam penelitian ini digunakan dua pendekatan, yaitu pendekatan undang-undang dan pendekatan konseptual. Digunakannya pendekatan undang-undang karena objek penelitian ini terkait dengan berbagai peraturan perundang-undangan. Sedangkan pendekatan konseptual digunakan untuk mengkaji dan menganalisis pandanganpandangan dan doktrin-doktrin dalam ilmu hukum terkait dengan objek penelitian. Metode pengumpulan data dilakukan dengan memusatkan perhatian pada bahan-bahan tertulis berupa literatur hukum pidana dan peraturan perundangan-undangan yang berkaitan dengan masalah yang diteliti. Disamping itu juga dianalisis pendapat para pakar di media cetak baik majalah, koran, jurnal, ataupun hasil penelitian yang relevan dengan pokok permasalahan. Setelah data terkumpul dari hasil studi literer tersebut, kemudian diadakan reduksi data dengan jalan membuat abstraksi, yakni usaha membuat rangkuman inti. Langkah

${ }^{6}$ Muhammad Idrus, Metode Penelitian Ilmu Sosial, Erlangga, Yogyakarta, 2007, hlm. 35. 
selanjutnya adalah menyusun satuan-satuan yang mengandung makna bulat dan dapat berdiri sendiri. Satuan-satuan itu kemudian dikategorisasikan berdasarkan pikiran, intuisi, pendapat atau kriteria tertentu dan kemudian diberi label sesuai dengan pengelompokannya. Dari hasil pengelompokan tersebut kemudian dicocokkan dengan permasalahan yang diteliti menurut kualitas kebenarannya sehingga dapat digunakan untuk memberikan jawaban atas permasalahan penelitian.

\section{Hasil Penelitian dan Pembahasan}

\section{Kriteria Perilaku Menyimpang dalam Praktik Bisnis Periklanan}

Kriteria atau standar penentuan kebenaran muatan informasi yang terdapat dalam suatu iklan terdapat dalam beberapa ketentuan perundang-undangan yang berlaku, seperti UU Nomor 8 Tahun 1999 tentang Perlindungan Konsumen (UUPK), Peraturan Pemerintah No.69 Tahun 1999 tentang Label dan Iklan Pangan, dan beberapa ketentuan yang bersifat administratif dari Menteri Kesehatan, Menteri Komunikasi dan Informasi, serta Kode Etik Periklanan. Kriteria atau standar penentuan suatu iklan yang menyesatkan dapat dilihat pada Pasal 10 UUPK 7 yang mengatur mengenai fakta material dan Pasal 17 ayat (1) UUPK ${ }^{8}$ yang mengatur mengenai konsumen rasional.

Terkait fakta material, suatu iklan dikategorikan mengandung pernyataan menyesatkan apabila pernyataan fakta materiil yang diungkapkan adalah salah atau tidak lengkap dan pihak yang melakukannya mempunyai maksud untuk

${ }^{7}$ Pasal 10 UUPK: Pelaku usaha dalam menawarkan barang dan/atau jasa yang ditujukan untuk diperdagangkan dilarang menawarkan, mempromosikan, mengiklankan atau membuat pernyataan yang tidak benar atau menyesatkan mengenai:

1. harga atau tarif suatu barang dan/atau jasa;

2. kegunaan suatu barang dan/atau jasa;

3. kondisi, tanggungan, jaminan, hak atau ganti rugi atas suatu barang dan/atau jasa;

4. tawaran potongan harga atau hadiah menarik yang ditawarkan;

5. bahaya penggunaan barang dan/atau jasa.

${ }^{8}$ Pasal 17 ayat (1) UUPK: Pelaku usaha periklanan dilarang memproduksi iklan yang:

1. mengelabui konsumen mengenai kualitas, kuantitas, bahan, kegunaan dan harga barang dan/atau tarif jasa serta ketepatan waktu penerimaan barang dan/atau jasa;

2. mengelabui jaminan/garansi terhadap barang dan/atau jasa;

3. memuat informasi yang keliru, salah, atau tidak tepat mengenai barang dan/atau jasa;

4. tidak memuat informasi mengenai risiko pemakaian barang dan/atau jasa;

5. mengeksploitasi kejadian dan/atau seseorang tanpa seizin yang berwenang atau persetujuan yang bersangkutan;

6. melanggar etika dan/atau ketentuan peraturan perundangundangan mengenai periklanan. 
melakukan penipuan. Di samping itu, pihak yang mengajukan pengungkapan mengenai terdapatnya pernyataan iklan yang salah (misrepresentation) harus pula menunjukkan bagian yang mana dari pernyataan iklan tersebut yang mengandung kesalahan dengan disertai bukti-bukti yang kuat, seperti keterangan ahli atau hasil test. Namun hal penting yang perlu diingat adalah klaim yang salah tersebut bukan berarti bersifat menipu dengan sendirinya, tetapi konsumen perlu percaya terlebih dahulu kepada sebuah klaim, baru kemudian dapat tertipu olehnya.

Dalam proses pemeriksaan pengaduan iklan di Negara Amerika Serikat dan Inggris, harus dibuktikan apakah fakta yang terdapat dalam iklan tersebut bersifat material atau tidak bagi konsumen. Walaupun telah nyata adanya unsur penyesatan dalam iklan, tetapi apabila fakta tersebut tidak bersifat material, maka iklan tersebut tidak dapat dikategorikan menyesatkan konsumen. ${ }^{9}$ Sebuah klaim yang salah tidak akan membahayakan konsumen kecuali jika dipercaya, dan sebuah klaim yang benar dapat membahayakan jika menimbulkan kepercayaan yang salah. ${ }^{10}$ Dalam konteks ini, standar informasi iklan yang menyesatkan didasarkan adanya fakta material yang dapat mempengaruhi konsumen dalam memutuskan untuk melakukan pembelian. ${ }^{11}$ Pengertian tersebut dapat dijadikan sebagai salah satu ukuran untuk menilai apakah suatu iklan yang ditayangkan dapat dikategorikan menyesatkan atau tidak, dengan mengukur materialitas informasi yang terdapat dalam iklan berkenaan dengan keputusan konsumen dalam melakukan pembelian, dalam hal ini konsumen rasional. ${ }^{12}$

Terkait konsumen rasional, definisi yang dapat diberikan adalah konsumen yang dalam memilih atau membeli barang dan/atau jasa yang dibutuhkan, benarbenar didasarkan atas pertimbangan yang matang berdasarkan informasi yang diterimanya melalui iklan. ${ }^{13}$ Dalam memberikan pertimbangan untuk memilih

${ }^{9}$ Daniel R. Bariskin, QC \& Jennifer Mc Kenzie, “Comparative Advertising, Canada and the United States", Toronto, November 2001, hlm. 21.

${ }_{10}$ Dedi Harianto, Perlindungan Hukum Bagi Konsumen terbadap Iklan yang Menyesatkan, Ghalia Indonesia, Bogor, 2010, hlm. 114.

${ }^{11}$ Fakta materian yang dianut oleh Federal Trade Commission di Amerika Serikat dalam kasus Exposition Press Inc. vs FTC.293 F.2d 869 (2d Cir. 1961) berpendapat "material here refers to a fact which influences some cunsomers action or decision usually (but not necessarily) the purchase decision". Lihat David A Rice, Consumer Transaction, Little Brown and Company, Boston, 1975, hlm. 202.

${ }^{12}$ Anne Keaty, Roger J John, Lucy L. Henke, "Can Internet Service Providers and Other Secondary Partiesbe Held Liable for Deceptive Online Advertising”, The Business Lanyer, Vol.58, 2002, hlm. 10.

13Ibid., hlm. 10. 
atau membeli produk misalnya, konsumen rasional akan mempergunakan kemampuan akal pemikiran serta pengetahuan yang dimilikinya untuk menilai informasi yang diperolehnya melalui iklan, serta menghindarkan keterlibatan aspek emosional. ${ }^{14}$ Upaya untuk melakukan evaluasi dampak informasi iklan terhadap konsumen rasional berkaitan dengan tingkat kepercayaan konsumen terhadap muatan informasi dalam iklan. Apakah informasi iklan yang menyesatkan tersebut benar-benar dipercaya oleh konsumen, sehingga dijadikan panduandalam menentukan pilihan, atau konsumen dama sekali tidak mempercayai muatan informasi iklan menyesatkan tersbut, sehingga tidak dijadikan panduan dalam menentukan pilihan. ${ }^{15}$

Kriteria ini perlu dipertimbangkan karena iklan dibuat untuk ditujukan kepada khalayak sasaran tertentu, berdasarkan tingkat pendidikan, kapasitas intelektual, kerangka pemikiran, dan sebagainya. Misalnya jika sebuah perusahaan memasarkan obat untuk penyakit mematikan, maka iklan obat tersebut akan dievaluasi dengan melihat bagaimana efeknya terhadap anggota suatu kelompok tertentu yang menderita penyakit mematikan tersebut. Konsumen dengan penyakit tersebut tentunya akan terpengaruh dengan klaim-klaim penyembuhan yang dibesar-besarkan. Demikian pula iklan suatu produk otomotif yang menawarkan berbagai fitur keselamatan dan keamanan dalam berkendara dari segala bahaya kecelakaan di jalan raya. Evaluasi akan dilakukan dengan melihat efek iklan produk otomotif tersebut dengan pilihan konsumen dalam melakukan pembelian produk otomotif. 16

\section{Bentuk-bentuk Perilaku Menyimpang dalam Praktik Bisnis Periklanan}

Terkait dengan bentuk-bentuk perilaku menyimpang dalam praktik bisnis periklanan meliputi pengungkapan pernyataan tidak benar (false statement), pemberian informasi yang menyesatkan (mislead statement), pengungkapan opini subjektif berlebihan (puffery), serta pengungkapan pernyataan yang bertentangan dengan kesopanan, moral, dan kesusilaan sebagaimana diuraikan di bawah ini.

${ }^{14}$ Dedi Harianto, Op. Cit., hlm. 128-129.

${ }^{15}$ Ibid., hlm. 128.

${ }^{16}$ Dedi Harianto, "Standar Penentuan Informasi Iklan Menyesatkan”, Jurnal Equality, Vol. 13, No. 1, 1 Februari, 2008, hlm. 46. 
Bentuk pertama dari perilaku menyimpang dalam praktik bisnis periklanan adalah pengungkapan pernyataan tidak benar (false statement). Dikatakan sebagai pernyataan tidak benar apabila fakta material yang diungkapkan adalah salah ataupun tidak lengkap dan pihak yang melakukannya mempunyai maksud untuk melakukan penipuan. Dari segi konten informasi yang disampaikan dalam iklan sangat mungkin mengandung unsur kebohongan, dibuat-dibuat, mengungkapkan hal-hal yang tidak benar untuk mengelabui konsumen agar tertarik membeli barang dan/atau jasa yang ditawarkan. Dalam konteks yang luas, konsumen dikatakan tertipu oleh iklan karena impresi atau kesan yang diberikan dalam klaim iklan tersebut adalah salah atau terdapat ketidaksesuaian antara klaim dengan fakta yang ada. ${ }^{17}$

Pengungkapan pernyataan tidak benar ini dapat kita lihat dari iklan XL yang gambar visualnya adalah orangutan dan mengusung tagline 'Bayar 1 Menit Gratis Nelpon dan SMS $17 \mathrm{Jam}^{\prime}$. Penyedia jasa dalam hal ini ingin mempengaruhi kesadaran konsumen dengan cara menyembunyikan informasi yang sebenarnya. Dengan memakai frase 'bayar 1 menit' pelaku usaha ingin menunjukkan bahwa produknya paling murah, sebab semua akan berpikir murah untuk ukuran telepon hanya 1 menit. Dalam konteks ini kuantitas dimanipulasi, padahal tidak mungkin bayar murah 1 menit jika ada gratisan sampai 17 jam.

Pernyataan iklan yang tidak benar atau salah juga tergambar dalam klain iklan Coca Cola Co yang memuat kalimat 'It's pure pasteurized juice as it comes from the orange'. Frase dalam iklan ini mengandung pernyataan yang salah karena kesegaran jus jeruk yang dihasilkan dari proses pasteurisasi tentu mempunyai kualitas yang berbeda dengan kesegaran jus jeruk yang dihasilkan dari buah jeruk segar. Hal ini sebagai dampak dari dilaksanakannya proses pengawetan dengan metode pemanasan hingga temperatur tertentu. ${ }^{18}$

Contoh lain dari informasi iklan yang tidak benar adalah iklan yang mengklaim bahwa tanah yang diiklankan sangat sesuai peruntukannya bagi pemukiman, peternakan, maupun lahan pertanian, dengan tema utama tanah

${ }^{17}$ Anne Keaty, Roger J John, Lucy L. Henke Op. Cit., hlm. 116.

${ }^{18}$ Kasus Coca Cola Co v. v. Tropicana Prod. Inc. (690 F.2d 312, 318 (2d Cir. 1982). Lihat Dedi Harianto, Op. Cit., hlm. 114. 
tersebut adalah investasi yang sangat baik dan aman. Namun dalam kenyataannya kondisi tanah tersebut sangat gersang sehingga membutuhkan dana yang besar untuk memungkinkannya menjadi daerah pemukiman, peternakan, dan pertanian seperti yang digambarkan dalam iklan.

Bentuk kedua dari perilaku menyimpang dalam praktik bisnis periklanan adalah pemberian informasi yang menyesatkan (mislead statement). Iklan yang menyesatkan terjadi apabila iklan tersebut sebenarnya memuat informasi yang benar tetapi informasi tersebut dapat menimbulkan persepsi yang salah atau mengelabui konsumen. Iklan yang menyesatkan dimungkinkan juga walaupun pernyataan yang terdapat dalam iklan tersebut tidak secara nyata mengandung unsur penyesatan, namun konsumen dapat memperoleh kesimpulan yang salah akibat informasi yang terkandung dalam klaim iklan tersebut. ${ }^{19}$ Ada dua kategori iklan yang menyesatkan, yaitu penyesatan menyangkut harga dan penyesatan dalam bentuk promosi. Penyesatan menyangkut harga terkait disampaikannya tingkat harga tertentu seakan-akan harga itu merupakan harga (rendah) yang terbaik bagi konsumen dibandingkan dengan harga produk yang sama dari produk pesaingnya. Penawaran harga 'obral', 'paling murah', 'beli rumah dapat parabola', dan lain-lain pernyataan sejenis merupakan contoh klaim iklan yang dapat menyesatkan. Sasaran dari iklan seperti itu adalah memberikan kesan kepada konsumen tentang adanya tingkat harga barang tertentu yang ditawarkan, namun tidak disebutkan harga murah itu dibandingkan dengan harga yang mana.

Klaim iklan yang menyesatkan dapat dilakukan dengan cara-cara melebihlebihkan kualitas, sifat, atau kemampuan suatu produk, membuat gambaran yang keliru tentangnya, memainkan syarat-syarat garansi suatu produk, memancing konsumen untuk mengunjungi tempat penjualan dengan kondisi yang menarik tetapi kemudian menawarkan produk lain dengan kondisi yang lain pula. Beberapa contoh klaim iklan menyesatkan yang digunakan antara lain: 'Nomor 1', 'Prima', 'Terbuat dari bahan alami' (dengan menghadirkan sayur dan buah tertentu), dan lain-lain pernyataan yang menyertainya.

${ }^{19}$ Dedi Harianto, Op. Cit., hlm. 119. 
Contoh lain iklan yang menyesatkan ini dapat dilihat pada kasus Johnson \& Johnson Merek Consumer Pharm Corp. versus Smithkline Beecham Corp. ${ }^{20}$ Pada kasus tersebut, Smithkline Beecham Corp. mempromosikan produk antacid dengan kelebihannya tidak mengandung aluminium dalam komposisi produknya, sedangkan produk kompetitor pada umumnya mengandung alumuium. Walaupun informasi itu pada dasarnya tidak salah, namun kompetitor mengkhawatirkan dampak informasi tersebut dapat menimbulkan persepsi yang salah kepada konsumen, di mana keberadaan alumunium dalam komposisi pruduk dapat dianggap sebagai bahan berbahaya. ${ }^{21}$

Iklan Listerine juga bisa dikategorikan sebagai iklan yang menyesatkan. Dalam berbagai tayangan iklannya, dimuat informasi mengenai kegunaannya, yakni selain sebagai pembersih mulut juga diklaim sebagai obat pencegah pilek dan radang tenggorokan. ${ }^{22}$ Namun dalam kenyataannya, Listerine tidak mempunyai khasiat mencegah pilek dan radang tenggorokan. Dalam iklan ini penyesatan informasi dilakukan dalam bentuk penyesatan terhadap kegunaan suatu barang untuk tujuan yang bukan merupakan kegunaan barang tersebut karena konsumen tidak akan memperoleh manfaat sebagaimana dinyatakan melalui pesan-pesan iklan tersebut. ${ }^{23}$

Klaim iklan Sosis So Nice JMS juga dapat dikategorikan sebagai pelanggaran terhadap etika periklanan. Ada kesan manipulatif di situ dengan kata-kata 'ingin jadi juara? makan So Nice'. Klaim iklan ini dapat dikatakan sangat provokatif karena tidak ada jaminan bahwa dengan makan So Nice maka seseorang akan menjadi juara. Ditambah lagi apakah ada jaminan bahwa bintang iklan tersebut juga mengkonsumsi So Nice sehari-harinya. Jadi dapat dikatakan bahwa iklan seperti ini cenderung menyesatkan konsumen.

Contoh iklan menyesatkan yang lain adalah 'jeruk minum jeruk' dalam iklan Nutrisari. Perumpamaan 'jeruk minum jeruk' tersebut dapat menimbulkan kesimpulan yang salah terhadap konsumen, di mana timbul pemahaman dengan

${ }^{20}$ Jhonson \& Jhonson "Merck Consumer Pharm.Co. v. SmithklineBeechamCorp., 960 F.2d 294, 297 (2d Cir. 1992).

${ }^{21}$ Dedi Harianto, Op. Cit., hlm. 115.

${ }^{22}$ Warner-Lambert v. FTC, 562F.2d.799.762 DC Cir 1977.

23Dedi Harianto, Op. Cit., hlm. 119. 
mengkonsumsi Nutrisari sama khasiatnya dengan mengkonsumsi buah jeruk segar. Padahal dalam label komposisi disebutkan bahwa Nutrisari terdiri dari ekstrak buah jeruk, bukan jeruk buah asli. ${ }^{24}$ Juga ada iklan lain yang menjurus ke penyesatan terhadap konsumen, seperti: 'Sunligh mencuci 5 kali lebih cepat', 'Pantene memberikan perlindungan anti ketombe tak terkalahkan', 'Clear menghilangkan ketombe dan gak balik lagi', 'UII memiliki rating Perguruan Tinggi terbaik se Indonesia', 'Vixal 10 kali lebih tangguh membersihkan noda membandel', 'Head and Shoulder shampoo anti ketombe lebih baik dari shampoo terkemuka', 'Pantine, tidak seperti shampoo biasa rambut patah berkurang', 'Wipol 4 kali membunuh kuman lebih cepat', 'Detol memberi perlindungan 100\%', 'Buavita mengandung 3 kali lebih banyak buah'. Klaim iklan-iklan tersebut di atas dapat dikategorikan sebagai pemberian informasi yang menyesatkan (misleading statement).

Bentuk ketiga dari perilaku menyimpang dalam praktik bisnis periklanan adalah pengungkapan opini subjektif yang berlebihan (puffery). Dalam kategori ini titik tekannya ada pada penggunakan statemen yang cenderung berlebihan dari yang seharusnya. Apa yang disampaikan memang ada dalam iklan tersebut tetapi dengan penyampaian yang terlalu hiperbolik. Contohnya adalah iklan Pizza Hut yang memuat slogan 'Better Ingredients, Better Pizza'. Slogan iklan semacam ini dianggap mengandung unsur klaim berlebihan (puffery) sehingga oleh Pengadilan Pizza Hut, Inc. dilarang meneruskan tayangan iklan tersebut. ${ }^{25}$ Contoh lain iklan yang memuat pernyataan yang berlebihan adalah 'dapat menyembuhkan berbagai pernyakit'.

${ }^{24}$ Ibid., hlm.120-121.

${ }^{25}$ William H. Brewster, Michael W. Rafter, Tywanda Harris Lord, Lisa Pearson, and Sabina A. Vayner, Advertising Basics, Pizza Hut v. Papa John's provides a good example of how the context of an advertisement can transform a statement that otherwise might be puffery into an actionable statement of fact. In that case, Pizza Hut sued Papa John's for use of the advertising slogan "Better Ingredients. Better Pizza." The court reasoned that "it is clear that the assertion by Papa John's that it makes a 'Better Pizza' is a general statement of opinion regarding the superiority of its product over all others. This simple statement . . . epitomizes the exaggerated advertising, blustering, and boasting by a manufacturer upon which no consumer would reasonably rely." The court continued that "it is difficult to think of any product, or any component of any product, to which the term 'better,' without more, is quantifiable," and concluded that the four word slogan, taken as a whole, was non-actionable puffery. Lihat http://www.kilpatricktownsend.com/ /media/Files/articles/LPearsonAdvertisingBasics.ashx. 
Iklan kartu perdana XL yang mengusung tagline 'Ngga Usah Mikir, Pake XL Pasti Termurah' yang dilanjutkan dengan 'Bayar 1 Menit Gratis Nelpon dan SMS 17 $J^{\prime} m^{\prime}$ jelas-jelas merupakan bentuk opini subjektif yang cenderung dilebih-lebihkan. Frasa 'Ngga Usah Mikir' menyalahi kaidah konsumen rasional yang seharusnya konsumen mesti berpikir bahkan kritis dalam menentukan pilihan terhadap suatu produk tertentu. Contoh lain adalah iklan Yamaha yang dibintangi Valentino Rossi yang memuat penyataan 'Yahama nomor 1', 'juara irit', 'juara cepat'. Hal yang sama juga terjadi pada iklan Shampo Clear yang mengusung jargon 'Shampo Antiketombe No.1'. Klaim dalam iklan tersebut jelas menunjukkan frase yang hiperbolik, superlatif, dan manipulatif karena tidak ada bukti bahwa produk tersebut nomor 1, paling irit, dan paling cepat.

Bentuk keempat dari perilaku menyimpang praktik bisnis periklanan adalah pengungkapan pernyataan bertentangan dengan kesopanan, moral, dan kesusilaan. Kategori tidak sopan atau tidak layak menurut masyarakat sangat beragam, salah satunya adalah iklan yang mengarah ke erotisme seperti iklan pompa air Shimizu. Yang ditampilkan oleh iklan ini adalah wanita seksi bersama suaminya yang berniat membeli obat kuat, akan tetapi ditawari pompa air dengan dibumbui kata-kata 'kalo gak mancur terus, kapan enaknya?', 'semburannya kuat', 'sedotannya kenceng'. Iklan semacam ini lebih mengarah ke erotisme ketimbang kondisi pompa air itu sendiri karena kata-kata yang disampaikan konotasinya mengarah ke pornografi.

\section{Aktivitas Bisnis Periklanan dalam Perspektif Hukum Pidana dan Penegakan Hukumnya}

Standar penetapan iklan menyimpang sebagai perbuatan pidana mengacu kepada peraturan perundang-undang yang berlaku. Dalam konteks ini peluang untuk pengenaan sanksi pidana terhadap pelanggaran ketentuan periklanan dimungkinkan berdasarkan ketentuan undang-undang hukum pidana yang bersifat umum seperti KUHP maupun ketentuan yang bersifat khusus seperti Undang-Undang Nomor 8 Tahun 1999 tentang Perlindungan Konsumen. Untuk KUHP, perilaku menyimpang di bidang periklanan merujuk pada Pasal 378 tentang Penipuan dan 382 bis tentang Perbuatan Curang. 
Unsur-unsur delik yang terkandung dalam Pasal 378 KUHP adalah: (1) menguntungkan diri sendiri secara melawan hukum; (2) dengan tipu muslihat atau rangkaian kebohongan; (3) menggerakkan orang lain menyerahkan barang sesuatu kepadanya. Sementara itu unsur-unsur delik dalam Pasal 382 bis KUHP meliputi: (a) melakukan suatu perbuatan menipu; (b) perbuatan itu mengelirukan orang banyak atau seseorang tertentu; (c) perbuatan itu dilakukan untuk menarik suatu keuntungan dalam perdagangan atau perusahaan sendiri atau orang lain; (d) perbuatan itu dapat menimbulkan kerugian bagi saingannya.

Undang-undang di luar KUHP yang mengatur aktivitas bisnis periklanan adalah Undang-undang Nomor 8 Tahun 1999 Pasal 17 ayat (1) yang berbunyi: Pelaku usaha periklanan dilarang memproduksi iklan yang: (a) mengelabui konsumen mengenai kualitas, kuantitas, bahan, kegunaan dan harga barang dan/atau tarif jasa serta ketepatan waktu penerimaan barang dan/atau jasa; (b) mengelabui jaminan/garansi terhadap barang dan/atau jasa; (c) memuat informasi yang keliru, salah atau tidak tepat mengenai barang dan/atau jasa; (d) tidak memuat informasi mengenai risiko pemakaian barang dan/atau jasa; (e) eksploitasi kejadian dan/atau seseorang tanpa seizin yang berwenang atau persetujuan yang bersangkutan; (f) melanggar etika dan/atau ketentuan peraturan perundang-undangan mengenai periklanan; (g) pelaku usaha periklanan dilarang melanjutkan peredaran iklan yang telah melanggar ketentuan pada ayat (1).

Dari uraian tersebut di atas dapat disimpulkan bahwa secara substantif pelanggaran di bidang periklanan dapat diantisipasi dengan ketentuan hukum pidana, baik yang diatur di dalam KUHP maupun yang diatur di luar KUHP seperti Undang-undang Perlindungan Konsumen. Namun dalam tataran praktik di lapangan, masih terjadi perbedaan pendapat di kalangan para ahli dan penegak hukum. Pertanyaan yang sering diajukan adalah apakah perilaku menyimpang dalam praktik bisnis periklanan tersebut sudah masuk ke ranah pidana atau belum. Permasalahan tersebut muncul dikarenakan adanya perbedaan sudut pandang di dalam menentukan suatu kegiatan bisnis sebagai suatu perbuatan pidana atau bukan. Mungkin saja sekelompok orang di suatu negara beranggapan bahwa 
praktik bisnis tertentu sebagai suatu perbuatan pidana, namun di pihak lain justru hanya menganggap sebagai perbuatan melawan hukum yang bersifat privat.

Perbedaan pandangan itu muncul karena ada perbedaan pemahaman terkait istilah yang digunakan, yaitu business tort dan business crime yang terdapat dalam literatur. ${ }^{26}$ Business tort secara umum diartikan sebagai aktivitas bisnis (termasuk bisnis periklanan) yang dalam tindakannya diketahui 'melawan hukum' baik ada unsur kesengajaan maupun kelalaian. Dalam konteks ini business tort diartikan sebagai perbuatan tidak terpuji yang biasanya dilakukan para pelaku bisnis tetapi tidak dianggap sebagai kejahatan. Dalam business tort telah terjadi pelanggaran terhadap hak-hak perseorangan (private rights) sehingga unsur kerugian dari kacamata hukum sulit diidentifikasi. Sementara itu, business crime lebih eksplisit dari pada business tort. Business crime dapat diartikan sebagai perbuatan tercela yang dilakukan oleh pelaku usaha, baik demi keuntungan bisnis atau yang merugikan suatu bisnis. ${ }^{27}$ Dalam business crime, aktivitas yang dijalankan memang jelas-jelas merupakan pelanggaran hukum yang mengacu pada pidana, misal mengiklankan produk-produk terlarang. Termasuk juga dalam business crime adalah setiap usaha yang dilakukan pelaku bisnis berdasarkan asas menghalalkan segara cara. Efek business crime tidak lagi bersifat personal, tetapi menyangkut hajat hidup banyak orang.

Walaupun rumusan delik dalam KUHP maupun undang-undang Perlindungan Konsumen nampaknya sudah memberikan harapan karena sudah diatur secara detail mengenai aktivitas bisnis di bidang periklanan, namun untuk penegakan hukumnya masih terdapat beberapa permasalahan yang masih harus dijawab agar Undang-undang tersebut dapat bekerja lebih efektif. Berkaitan dengan penegakan hukum ini, masalah penting yang perlu mendapat perhatian adalah masalah pembuktian, sarana atau fasilitas yang mendukung, profesionalitas dan sikap mental aparat penegak hukum, sikap mental pelaku bisnis maupun masyarakat pada umumnya.

${ }^{26}$ Sunaryati Hartono, "Kemungkinan Penerapan Sanksi Pidana Terhadap Praktik-praktik Bisnis Internasional”, Makalah Seminar Aspek-aspek Pidana dalam Kegiatan Dunis Usaha”, Babinkumnas, Jakarta, 1985, hlm. 5-6.

${ }^{27}$ Ibid. 
Kesulitan pembuktian merupakan kelemahan yang paling krusial dalam penegakan hukum. Menghadapi permasalahan pembuktian ini maka aparat penegak hukum selalu bertindak hati-hati untuk menindaklanjuti suatu kasus apabila kasus itu dianggapnya tidak mempunyai bukti yang kuat. Masalah lainnya adalah korban yang bersifat abstrak dan kolektif sehingga tidak disadari bahwa mereka telah menjadi korban. Sebagai contoh, pemberian keterangan tidak benar atas suatu produk baik melalui label produk maupun melalui iklan. Dalam kasus seperti ini terdapat korban yang bersifat abstrak dan kolektif. Dikatakan abstrak, karena korban dari kasus itu tidak jelas. Dikatakan kolektif, karena korbannya banyak dan meluas di masyarakat. Kelemahan tersebut didukung oleh ketiadaan atau ketidaklengkapan sarana atau fasilitas seperti laboratorium untuk menguji produk yang beredar di masyarakat. ${ }^{28}$ Kelemahan ini ditambah lagi dengan kurangnya profesionalitas aparat penegak hukum di bidang perkembangan ilmu pengetahuan dan teknologi yang mengikuti tindak pidana tersebut.

Sikap mental aparat penegak hukum dan pelaku usaha juga merupakan faktor yang menghambat dalam penegakan hukum di bidang bisnis. Kuatnya posisi pelaku bisnis dapat mempengaruhi pemerintah dan anggota legislatif untuk membuat peraturan yang sesuai dengan kehendak mereka. Sikap mental aparat penegak hukum yang mudah dipengaruhi oleh pelaku usaha dengan hanya diberikan sekedar uang suap sudah merupakan hambatan tersendiri. Bahkan tidak jarang pengadilan pun dapat dipengaruhi oleh mereka sehingga penegakan hukum pidana jauh dari yang diharapkan.

Yang lebih ironis lagi dalam penegakan hukum pidana di bidang bisnis ini adalah tidak adanya kesadaran dari para pelaku bisnis. Mereka selalu berdalih bahwa apa yang mereka kerjakan bukan perbuatan yang illegal dan unethical dan seharusnya dapat dimaklumi. Sikap umumnya pelaku bisnis ini cukup memprihatinkan karena secara psikologis mereka tidak menyadari bahwa perbuatannya merupakan kejahatan. Mereka selalu mengatakan, benar illegal but not criminal, sebab menurut anggapan mereka criminal adalah termasuk golongan

${ }^{28}$ Ahmad Zazili dan Hartono, "Model Pemberdayaan Konsumen terhadap Ancaman Bahaya Produk Pangan Tercemar Bahan Berbahaya Beracun di Provinsi Lampung", Jurnal Hukum IUS QULA IUSTUM, Volume 23, Nomor 3, Juli, 2016, hlm.401. 
street crime atau kejahatan konvensional yang korban-korbannya jelas seperti pembunuhan, pencurian, perampokan, perkosaan, dan lain-lain yang sejenis. Sedangkan mereka sendiri yang oleh pengamat dan pakar kriminologi dipandang sebagai white collar crime tidak merasakan bahwa tindakannya itu lebih merugikan daripada street crime. ${ }^{29}$ Pelanggar-pelanggar hukum itu tidak merasa dirinya sebagai 'pelaku kejahatan' dan sering dalam lingkungan bisnis, handai taulan, dan keluarganya juga mempunyai pandangan yang sama. Mereka selalu dipandang oleh lingkungannya sebagai warga yang terhormat. Sementara itu, di lingkungan usaha menganggap bahwa perbuatan itu bukan kejahatan (business crime) tetapi sekedar pelanggaran suatu permainan (business tort).

Sikap mental seperti diuraikan di atas itulah yang pada akhirnya juga mempengaruhi terhadap aparat penegak hukum sehingga mereka ragu-ragu menjatuhkan pidana terhadap aktivitas bisnis menyimpang di bidang periklanan ini. Berkaitan dengan masyarakat khususnya konsumen, di samping sikap mental untuk selalu 'pasrah', menerima saja atas perlakuan produsen, juga adanya sikap mental yang tidak mau sulit untuk berperkara ke pengadilan. Ditambah lagi sebagian besar masyarakat berada dalam posisi yang lemah, sehingga tidak mempunyai kekuatan di dalam menghadapi pelaku ekonomi yang pada umumnya mempunyai economic power dan political power yang jauh lebih kuat. Problematika terakhir yang juga menghambat adalah berkaitan dengan political will pemerintah. Kebijakan pembangunan pemerintah lebih diarahkan kepada pertumbuhan ekonomi sehingga terjadi 'pengabaian' dalam pembangunan di bidang lain. Di bidang hukum misalnya, sering dianggap sebagai faktor yang dapat menghambat perkembangan di bidang ekonomi. Akibatnya, pembangunan di bidang hukum jauh tertinggal oleh perkembangan ekonomi. Jadi faktor political will dari pemerintah ini sangat menentukan dalam menunjang pembangunan di bidang hukum. Sekaligus faktor ini juga memberi saham yang tidak kecil dalam penegakan hukum secara keseluruhan

${ }^{29}$ Joseph F. Sheley, Exploring Crime: Reading in Criminology and Criminal Justice, Wodsworth Publishing Company, California, 1987, hlm. 210. 


\section{Penutup}

Dua kriteria yang dapat dijadikan sebagai acuan untuk menentukan apakah suatu iklan termasuk iklan yang menyimpang adalah fakta materian dan konsumen rasional. Sementara itu, bentuk-bentuk penyimpangan dalam penayangan informasi iklan melalui media cetak maupun elektronik terdiri dari memberikan informasi secara keliru, salah, ataupun tidak tepat mengenai kondisi barang dan/atau jasa (false statement); pernyataan yang tidak sesuai dengan kondisi produk yang sebenarnya atau menyesatkan (mislead statement); memberikan gambaran secara tidak lengkap terhadap barang dan/atau jasa (omission); memberikan informasi atau opini yang berlebihan tanpa didukung fakta mengenai kualitas, sifat, kegunaan, ataupun kemampuan barang dan/atau jasa (puffery); serta iklan yang bertentangan dengan kesopanan, moral, dan kesusilaan.

Dalam perspektif hukum pidana, sebagian besar perilaku menyimpang dalam praktik bisnis periklanan dapat dikategorikan sebagai perbuatan pidana. Ketentuan mengenai hal tersebut dapat ditemukan dalam undang-undang yang bersifat umum seperti Kitab Undang-undang Hukum Pidana (KUHP) maupun undang-undang yang bersifat khusus yang mempunyai sanksi pidana seperti Undang-undang Perlindungan Konsumen. Yang menjadi permasalahan dalam hukum pidana adalah terkait dengan penegakan hukumnya. Permasalahan penegakan hukum ini terutama menyangkut persepsi yang tidak sama antara masyarakat dengan penegak hukum dalam mensikapi perilaku menyimpang di bidang periklanan. Sebagian kalangan beranggapan bahwa iklan yang menyimpang itu masuk kategori business tort yaitu perbuatan tidak terpuji, bukan perbuatan pidana. Namun sebagian kalangan menganggap perilaku menyimpang dalam praktik bisnis periklanan itu sudah masuk ke dalam kategori business crime sehingga masuk dalam kategori perbuatan pidana. Faktor lain yang juga mempengaruhi penegakan hukum terhadap perilaku menyimpang dalam praktik bisnis periklanan adalah masalah pembuktian, sikap mental aparat penegak hukum maupun masyarakat, dan yang tidak kalah pentingnya adalah political will pemerintah dalam menertibkan penyimpangan-penyimpangan oleh pelaku bisnis di bidang periklanan. 


\section{Daftar Pustaka}

\section{Buku}

Liliweri, Alo, Dasar-dasar Komunikasi Periklanan, PT. Citra Aditya Bhakti, Bandung, 1992.

BPHN, “Naskah Akademis Peraturan Perundang-undangan tentang Perlindungan Konsumen dalam Hal Makanan dan Minuman", BPHN, Jakarta.

Bariskin, Daniel R., QC \& Jennifer Mc Kenzie. “Comparative Advertising in Canada and the United States", Toronto, November, 2001.

Rice, David A., Consumer Transaction, Little Brown and Company, Boston, 1975.

Harianto, Dedi, Perlindungan Hukum bagi Konsumen terhadap Iklan yang Menyesatkan, Ghalia Indonesia, Bogor, 2010.

Sigler, Jay A., Understanding Criminal Law, Little Brown and Company, Boston, 1981.

Sidabalok, Janus, Hukum Perlindungan Konsumen di Indonesia, PT. Citra Aditya Bakti, Bandung, 2006.

Sheley, Joseph F., Exploring Crime: Reading in Criminology and Criminal Justice, Wodsworth Publishing Company, California, 1987.

Moeljatno, Kitab Undang-Undang Hukum Pidana (KUHP), Cetakan ke-19, Bumi Aksara, Jakarta.

Lee, Monle \& Carla Johnson. Prinsip-prinsip Pokok Periklanan dalam Perspektif Global, Kencana Prenada Media Group, Jakarta, 2007.

Fuadi, Munir, Pasal Modal Modern (Tinjauan Hukum), PT Citra Aditya Bakti, 1996.

Oughton, David, dan Jhon Lowry, The Text Book on Consumer Law, Black Stone Press Limited, London, 1997.

Radhiyah, Etika Bisnis dan Keadilan Konsumen, tt.

\section{Hasil Penelitian}

Lazfihma, "Analisis Gaya Bahasa dalam Sloga Iklan Minuman di Televisi”, Skripsi, Program Studi Pendidikan Bahasa dan Sastra Indonesia, Fakultas Bahasa dan Seni, Universitas Negeri Yogyakarta, 2014.

\section{Artikel Jurnal}

Harianto, Dedi, "Standar Penentuan Informasi Iklan Menyesatkan”, Jurnal Equality, Vol. 13, No. 1, Februari, 2008.

Keaty, Anne, Roger J John, Lucy L. Henke. “Can Internet Service Providers and Other Secondary Partiesbe Held Liable for Deceptive Online Advertising", The Business Lawyer, Vol. 58, 2002.

Zazili, Ahmad, dan Hartono, "Model Pemberdayaan Konsumen terhadap Ancaman Bahaya Produk Pangan Tercemar Bahan Berbahaya Beracun di 
Provinsi Lampung", Jurnal Hukum IUS QUIA IUSTUM, Volume 23, Nomor 3, Juli, 2016.

\section{Makalah}

Hartono, Sunaryati, "Kemungkinan Penerapan Sanksi Pidana Terhadap Praktikpraktik Bisnis Internasional". Makalah Seminar Aspek-aspek Pidana dalam Kegiatan Dunis Usaha", Babinkumnas, Jakarta, 1985.

\section{Peraturan Perundang-undangan}

Kitab Undang-undang Hukum Pidana (KUHP)

Undang-Undang Nomor 8 Tahun 1999 tentang Perlindungan Konsumen (Lembaran Negara Republik Indonesia Tahun 1999 No, 42, Tambahan Lembaran Negara Republik Indonesia No. 3821).

Peraturan Pemerintah Nomor 69 Tahun 1999 tentang Label dan Iklan Pangan. 